\title{
МЕТОДИ ЛІКУВАННЯ ОЖИРІННЯ У ПІДЛІТКІВ
}

\author{
А. С. Артеменко ${ }^{1,2}$, Л. В. Наумова ${ }^{1}$ \\ ${ }^{1}$ ДВНЗ «Тернопільський державний медичний університет \\ імені І. Я. Горбачевського МОЗ Украӥни" \\ ${ }^{2}$ Нікопольський медичний коледж
}

У статті висвітлено особливості лікування ожиріння у підлітків. Проаналізовано принципи дієтотерапії, гіпнозу та оперативних втручань щодо корекції цього стану. Розглянуто основні моменти, на які необхідно звернути увагу під час лікування підліткового ожиріння.

\section{TREATMENT MODES OF OBESITY IN ADOLESCENTS}

\author{
A. S. Artemenko ${ }^{1,2}$, L. V. Naumova ${ }^{1}$ \\ ${ }^{1}$ I. Horbachevsky Ternopil State Medical University \\ ${ }^{2}$ Nikopol Medical College
}

The article highlights the features of obesity treatment in adolescents. The principles of diet therapy, hypnosis and surgical interventions according to this disorder are explained. The main points for attention during treatment of obesity in adolescents are described.

Вступ. Невпинний прогрес механізації та автоматизації багатьох процесів призводить до прогресивного зниження рухової активності серед населення. Новітні технології покращили матеріальний та соціальний рівень людей. На сьогодні доведено, що від ожиріння страждають малозабезпечені верстви населення, які споживають «дешеву» їжу, таку, як фаст-фуд. Люди, які мають високий соціальний рівень, їдять низькокалорійну їжу, морепродукти і т. д. Загалом у наш час кожен п'ятий українець зіткнувся з проблемою переїдання та надмірною масою тіла.

Ожиріння - найбільш помітна ознака порушення гомеостазу, розлад динамічної рівноваги між надходженням речовин та їх використанням. Це одна 3 головних проблем сучасної медицини. Під ожирінням розуміють характерний надлишок жирової тканини,

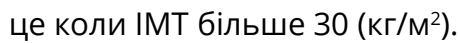

Актуальною проблемою є лікування цієї патології із використанням традиційних та нетрадиційних методів терапії. При цьому потрібно враховувати індивідуальність кожного пацієнта. Особливу увагу необхідно приділяти молодому поколінню. Статистика дослідження ожиріння на 2017 р. діагностувала зростання проблеми з віком [1].
Головною метою лікування ожиріння $€$ зменшення ризику виникнення та загострення супутніх захворювань. В ідеальному варіанті це повноцінна зміна стилю життя та харчування підлітка. Процес лікування тривалий та потребує зусиль як від хворого, так і від медичної команди [2].

Основна частина. Діагностика ожиріння ґрунтується на вимірюванні антропометричних даних, а зокрема оцінці співвідношення маси тіла (виміряної в кілограмах) до зросту пацієнта (в сантиметрах у квадраті), вимірюванні обхвату талії, стегон та визначення їх співвідношення. «Золотим» стандартом ведення хворих з ожирінням є дозоване фізичне навантаження та дієтотерапія. На сьогодні використовують гіпотрофічну дієту (зі зниженим вмістом жирів та легкозасвоюваних вуглеводів). Особливо необхідно звертати увагу на кратність прийомів їжі та якість харчових продуктів. Хворим з ожирінням необхідно п'ятиразове харчування дрібними, невеликими порціями. Приготовлені страви не повинні містити спеції, які збільшують апетит, легкозасвоювані вуглеводи, та належати до категорії фаст-фуд. Достатня кількість білків у раціоні запобігає білковому голодуванню та знижує відчуття голоду.

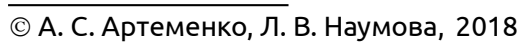


Визначення добової норми калорійності їжі підраховують за спеціально розробленою формулою. У різних країнах світу розроблено таблиці калорійності харчових продуктів для складання меню.

Найпопулярнішими є формули Харріса-Бенедикта та Міффлін-Сан Жеора.

Формулу Харріса-Бенедикта розраховують для жіночої статі: 447,593 додати (9,247 помножити на масу (кг)) додати (3,098 помножити на зріст (см)) відняти (4,330 помножити на вік людини). Для чоловічої статі: 88,362 додати (13,397 помножити на масу (кг)) додати (4,799 помножити на зріст (см)) відняти (5,677 помножити на вік людини).

Формула Міффлін-Сан Жеора. Для жіночої статі: (9,99 помножити на масу (кг)) додати (6,25 помножити на зріст (см)) мінус (4,92 помножити на вік людини) та відняти 161. Для чоловічої статі: (9,99 помножити на масу (кг)) додати (6,25 помножити на зріст (см)) відняти (4,92 помножити на вік людини) та додати 5.

За цими формулами найточніше розрахувати скільки калорій витрачає організм здорової людини в стані спокою. Залежно від того, який у вас спосіб життя, вибирають відповідний коефіцієнт:

- мінімальні навантаження (сидяча робота) - 1,2;

- трохи денної активності та легкі вправи 1-3 рази на тиждень - 1,375;

- тренування 4-5 разів на тиждень (або робота середньої тяжкості) - 1,4625;

- інтенсивні тренування 4-5 разів на тиждень 1,550;

- щоденні тренування - 1,6375;

- щоденні інтенсивні тренування або тренування 2 рази на день - 1,725;

- важка фізична робота або інтенсивні тренування 2 рази на день - 1,9.

Необхідно отримане число за формулою помножити на відповідний коефіцієнт.

Показники добової норми калорій для дітей і підлітків:

- 6-12 місяців - 850 Ккал;

- від 12 місяців до 3 років - 1600 Ккал;

- 4-6 років - 2000 Ккал;

- 7-10 років - 2300 Ккал;

- 10-14 - до 2700 Ккал.

Необхідно скласти правильне меню. Загальну добову енергетичну цінність поділяють: сніданок - $30 \%$, другий сніданок - 15 \%, обід - 35 \%, полудень - $10 \%$, вечеря - $10 \%$. Нежирне м'ясо, риба, клітковина, що міститься в овочах та фруктах, не лише стимулюють рух травного тракту, але й запобігають перетворенню вуглеводів у жири. Також можна споживати невелику кількість горіхів, щоб задовольнити фізіологічні потреби. Обмежуємо сіль та воду до 1,5 л на добу. 3 раціону необхідно вилучити цукор, шоколад, морозиво, тістечка, соуси, кетчуп, майонез, консерви та консервовані соки, фрукти. Харчування повинно покривати енергозатрати організму. Дієта для підлітків 3 ожирінням має бути збалансована, містити достатню кількість незамінних амінокислот, поліненасичених жирних кислот, вітамінів та інших мікроелементів.

Медикаментозне лікування проводять у разі неефективності дієтотерапії впродовж року або як комбінований метод. На сьогодні єдина група препаратів, використання яких дозволено відповідно до протоколів ведення дітей з ожирінням (від 11 років), бігуаніди. Нині доведена ефективність препаратів із групи ліраглутиду, емпагліфлозину та канагліфлозину, які мають здатність зменшувати масу тіла, проте, на сьогодні, не включені в протокольне ведення дітей з ожирінням.

Часто причиною збільшення маси тіла може бути порушення роботи щитоподібної залози, а саме ії гіпофункція, тому таким дітям рекомендована корекція тиреоїдними гормонами, під особливою увагою лікаря, відповідно до отриманих лабораторних та діагностичних показників.

Лікувальна фізична культура. При ожирінні фізичні навантаження розглядаються як невід'ємна частина терапії, показані підліткам при всіх формах та стадіях ожиріння. Вид фізичних навантажень, їх об'єм, інтенсивність та форма проведення залежить від супутніх захворювань пацієнта. Підліткам без хвороб серцевосудинної системи показані вправи на витривалість: ходьба, біг, плавання, гребля, ходьба на лижах або скандинавська ходьба. Фізичні навантаження повинні бути декілька разів на день кожного дня. Масаж - це складова частина загального лікування пацієнта. Також використовують санаторно-курортне лікування.

Психотерапія. Одна із важливих умов лікування ожиріння $\epsilon$ психотерапія. На початку лікування потрібно провести бесіду з пацієнтом про віру у власні шанси одужати. Можуть використовувати метод гіпнозу. За його допомогою можна перезавантажити психіку хворого та усунути шкідливі звички переїдати та заїдати стрес їжею. Такий метод лікування дає значні результати у втраті маси тіла [3-8].

Хірургічний спосіб лікування, як правило, використовують лише тоді, коли хвороба стала небез- 
печною для життя і здоров'я. Це так зване «морбідне» ожиріння, яке характеризується індексом маси тіла понад 50 та поєднується з різноманітними захворюваннями (цукровим діабетом, гіпертензією, захворюваннями суглобів, дихальною недостатністю тощо). Проте варто враховувати, що хірургічне лікування заборонено використовувати дітям до 18 років.

Існує декілька видів хірургічного лікування ожиріння, які сприяють зменшенню маси тіла: установка шлункового бандажа; установка внутрішньошлункового балона; шунтування шлунка; ліпосакція; кріоліполіз [9-13].

Лікування ожиріння хірургічним шляхом вимагає найвищої кваліфікації хірургів, навченого медичного персоналу та сучасного оснащення клініки. Найважливішим аспектом доброго результату в лікуванні $\epsilon$ чітке дотримання всіх рекомендацій лікаря після операції.

\section{СПИСОК ЛІТЕРАТУРИ}

1. Про затвердження норм фізіологічних потреб населення України в основних харчових речовинах і енергії [Електронний ресурс] : наказ МОЗ України від 03.09.2017 р. № 1073. - Режим доступу : http://zakon.rada. gov.ua/laws/show/z1206-17.

2. Большакова О. В. Ожиріння в дитячому та підлітковому віці / О. В. Большакова // Медична газета «Здоров'я України». - 2008. - 18 червня. - С. 50-53.

3. Мельник Н. О. Медико-соціальні наслідки ожиріння в підлітковому віці та роль медичної сестри в його попередженні / Н. О. Мельник // Вища освіта в медсестринстві: проблеми і перспективи : Всеукраїнська науково-практична конференція, 28-29 квітня 2010 р. - Житомир : Полісся, 2010. - С. 100.

4. Горобей М. П. Проблеми надлишкової ваги та ожиріння школярів і студентів / М. П. Горобей // Педагогіка, психологія та медико-біологічні проблеми фізичного виховання і спорту : зб. наук. пр. ; за ред. С. С. Єрмакова. Харків : ХДАДМ, 2012. - № 5. - С. 47-49.

5. Мельник Наталія Обґрунтування сестринської моделі попередження аліментарно-конституційного ожиріння у підлітків / Наталія Мельник // XV Міжнародний медичний конгрес студентів та молодих учених, 29-31 квітня 2011. Тернопіль : Укрмедкнига, 2011. - С. 84.
Висновки. Для правильного та адекватного лікування ожиріння необхідно застосовувати комплексну терапію. Лікувальні заходи при ожирінні в підлітковому віці вимагають акуратності в дотриманні рекомендацій, наполегливості, терпіння, оскільки процес лікування $\epsilon$ тривалим. Усі тонкощі лікувальної дії повинні бути обговорені лікарями і батьками хворих дітей. Фізична активність та дозоване фізичне навантаження $\epsilon$ невід'ємною частиною лікування підліткового та дитячого ожиріння. Масу тіла необхідно зменшувати поступово, намагаючись якнайдовше утримати досягнений результат. Раціон, кількість харчування вибирають індивідуально кожному пацієнту-дитині з урахуванням всіх особливостей хворого. Вказані методи лікування повинні проводити поступово та пожиттєво, з метою досягнення максимального ефекту.

6. Мельниченко Г. А. Ожирение: эпидемиология, классификация, патогенез, клиническая симптоматика и диагностика. В кн.: Ожирение / Г. А. Мельниченко, Т. И. Романцова; под ред. И. И. Дедова, Г. А. Мельниченко. - М. : Медицинское информационное агентство, 2014. - 456 c.

7. Ожирение у подростков / Т. Н. Сорвачева, В. А. Петеркова, Л. Н. Титова [и др.] // Лечащий врач. - 2016. № 4. - С. 50-54.

8. Большова О. М. Дієтотерапія при ожирінні у дітей та підлітків / О. М. Большова, Т. М. Маліновська // Лікарська справа. Врачебное дело. - 2008. - № 7/8. - С. 70.

9. Іващенко І. Ю. Нетрадиційні методи лікування ожиріння у дітей / І. Ю. Іващенко // Медсестринство. - 2013. № 1. - С. 53-56.

10. Корпачев В. В. Парадоксы ожирения / В. В. Корпачев // Здоров'я України. - 2016. - № 2. - С. 45.

11. Калмыков 3. А. Ожирение: профилактика и лечение / З. А. Калмыков. - К. : Медкнига, 2009. - 108 с.

12. Дієтологія / за ред. Н. В. Харченко, Г. А. Анохіної. К., 2012. -526 с.

13. Мищенко Н. К. Современные подходы к терапии ожирения / Н. К. Мищенко // Здоров'я України. - 2014. № 1. - C. 28. 